I. Я. Криницька, М. І. Марущак, І. М. Кліщ, Н. В. Петренко ДВНЗ “Тернопільський державний медичний університет імені І. Я. Горбачевського МОЗ Украӥни”

\title{
ІННОВАЦІЇ У МЕДИЧНІЙ ОСВІТІ: ІНТЕГРАТИВНИЙ ПІДХІД ДО ДІАГНОСТИКИ, ЛІКУВАННЯ ТА ПРОФІЛАКТИКИ ЗАХВОРЮВАНЬ
}

\author{
I. Ya. Krynytska, M. I. Marushchak, I. M. Klishch, N. V. Petrenko \\ I. Horbachevsky Ternopil State Medical University

\section{INNOVATIONS IN MEDICAL EDUCATION: INTEGRATED APPROACH TO DIAGNOSTICS, TREATMENT AND PREVENTION OF DISEASES}

\begin{abstract}
Мета роботи - проаналізувати переваги інтегративного підходу до вивчення діагностики, лікування та профілактики захворювань в освітньому процесі медичного університету.

Основна частина. Інтеграція України в міжнародне науково-освітнє співтовариство та реформування системи охорони здоров’я в Україні потребують впровадження в освітньо-інтегративний процес міжнародних медичних та освітніх стандартів. Однією із важливих компетентностей, якої має набути студент вищого медичного закладу, є клінічне мислення та інтегративний підхід до діагностики, лікування та профілактики захворювань.

Інтегративна медицина демонструє багаторівневий підхід до пацієнта з будь-якою патологією і передбачає співпрацю з таким пацієнтом на рівні його особистості, соматичної та психологічної проблеми та орієнтована на кінцеву мету - зміну стратегії та якості життя пацієнта, а не лише позбавлення його певного соматичного захворювання.

Висновок. Таким чином, принципи інтегративної медицини є найбільш перспективними для подальшого теоретичного розвитку і мають безумовні практичні переваги, оскільки, грунтуючись на ідеї єдиного механізму розвитку хвороб, обумовленого закономірними процесами життєдіяльності, передбачають більш раціональні шляхи пошуку ефективних засобів профілактики і лікування.
\end{abstract}

Ключові слова: навчальний процес; інтегративна медицина.

The aim of the work - to analyze the advantages of an integrative approach to the study of diagnosis, treatment and prevention of diseases in the educational process of the medical university.

The main body. The integration of Ukraine into the international academic community and health care reform in Ukraine need to be supported in the educational process of integrative international medical and educational standards. One of the important competences to be acquired by a student at a university is clinical thinking and an integrative approach to diagnosis, treatment and disease prevention. Integrative medicine demonstrates a multi-level approach to a patient with any pathology and involves cooperation with such a patient at the level of his personality, somatic and psychological problems and is aimed at the ultimate goal of changing the patient's strategy and quality of life, and not just depriving him of a particular somatic disease.

Conclusion. Thus, the principles of integrative medicine are the most promising for further theoretical development and have unconditional practical advantages, since, based on the idea of a single mechanism for the development of diseases, caused by the natural processes of life, provide more rational ways to find effective means of prevention and treatment.

Key words: learning process; integrative medicine.

Вступ. Сучасні вимоги до професійної підготовки майбутніх лікарів, зумовлені інтеграцією України в міжнародне науково-освітнє співтовариство та реформуванням системи охорони здоров'я в Україні, потребують впровадження в освітній процес міжнародних медичних та освітніх стандартів, підвищення інтелектуального, науково-освітнього, професійно-орієнтованого рівня майбутніх лікарів, забезпечення їх сучасними інноваційними та інформативними медичними технологіями [1].

() I. Я. Криницька, М. I. Марущак, I. М. Кліщ, Н. В. Петренко
Важливим у модернізації освітнього процесу у закладах вищої освіти є своєчасне виявлення i включення у навчальний план професійних компетентностей, які відповідатимуть потребам майбутнього професіонала [2]. Однією із важливих компетентностей, якої має набути студент вищого медичного закладу, $є$ клінічне мислення та інтегративний підхід до діагностики, лікування та профілактики захворювань.

Мета роботи - проаналізувати переваги інтегративного підходу до діагностики, лікування та 
профілактики захворювань в освітньому процесі медичного університету.

Основна частина. Сучасній медицині притаманна глибока диференціація. Внутрішня медицина поділилася на безліч дисциплін, що відрізняються об’єктом вивчення, методами дослідження, термінологією, тактичними прийомами лікування і профілактики. I сьогодні в рамках навіть одного напрямку намічаються межі більш тонкого поділу, наприклад, гепатологія в гастроентерології, аритмологія в кардіології [3].

Проте у щораз більшій різноманітності деталей поступово втрачається уявлення про цілісність організму, адже не існує локальних захворювань або хвороб окремих органів - хворіє завжди людина в цілому. Тому принципи інтегративної медицини $\epsilon$ найбільш перспективними для подальшого теоретичного розвитку і мають безумовні практичні переваги, оскільки, спираючись на ідею єдиного механізму розвитку захворювань, вони передбачають більш раціональні шляхи пошуку ефективних засобів профілактики і лікування.

Сьогодні підтверджується ідея Парацельса про величезне значення характеристики індивідуальних особливостей організму, про те, що “важливіше знати, ким є хвора людина, ніж те, на яку хворобу вона хворіє”. Згідно з цим положенням, інтегратизм $\epsilon$ не лише простим об’єднанням даних про індивідуума і його хвороби, але включає в себе і “взаємнопроникаючу” діагностичну технологію. Остання допомагає здійснити більш глибокий аналіз за рахунок врахування даних як про взаємозв’язки і взаємозалежності, так і про взаємопроникнення і “переплетення” факторів, що беруть участь у процесі, формуванні хвороби і змінюють їі, що в сукупності і визначає можливість отримати більш повний комплекс знань про індивідуума, його організм і його захворювання [4].

Ідея персоналізації, тобто розуміння необхідності індивідуального підходу до кожного пацієнта, існувала з самого початку розвитку медицини. Ще Гіппократ говорив, що потрібно “давати різні ліки різним пацієнтам; те, що добре для одного, може не бути корисним для іншого” [5]. “Інтегративна медицина” включає розробку персоналізованих засобів лікування на основі геноміки, тестування на схильність до хвороб, профілактику, об’єднання діагностики з лікуванням і моніторинг лікування” [5]. За даними D. C. Whitcomb, персоналізована медицина “інтегрує індивідуальну генетичну та іншу інформацію для попередження і лікування комплексних порушень на основі спостережень “від науки до клініки” (“from bench to bedside”) [6].

Мета інтегративної медицини полягає в тому, щоб “знайти відповідний лікарський препарат для конкретного хворого, і в деяких випадках навіть розробити схему лікування пацієнта відповідно до його індивідуальних даних". Необхідність цього обумовлена тим, що традиційні, створювані для лікування конкретного захворювання лікарські препарати виявляються неефективними для 30-60 \% пацієнтів поряд із високою частотою виникнення побічних ефектів [5].

Об’єктом інтегративної медицини є організм як біологічна система в тісному органічному зв’язку з біосферою, більш того, з ноосферою, як філогенетично, так і онтогенетично. Таке розуміння передбачає необхідність пошуків сутності хвороби як одного зі способів існування людини як біологічної системи. Сьогодні настав час зміни класичної парадигми теорії хвороби на сучасну, яку можна сформулювати наступним чином. Хвороба $є$ формою життєдіяльності організму, що виникає в результаті його пошкодження. Динаміка хвороби грунтується на утворенні нової патологічної суперсистеми, що забезпечує існування організму в біосфері в стані пошкодження за допомогою пристосування. Вона обмежена щодо еволюційно сформованого рівня адаптації в стані здоров'я і набуває особливостей завдяки додатковим взаєминам в ноосфері. Патологічна суперсистема складається з взаємозв’язаних і взаємодіючих функціональних підсистем, пов'язані зміни в яких є наслідком ушкоджень і пристосувальних реакцій. Сформована суперсистема забезпечує пристосування до навколишнього середовища, проте рівень такої адаптації знижений щодо стану здоров' я, що обмежує життєдіяльність у просторі і часі (тривалості життя) [7].

Основні підходи інтегративної медицини включають в себе такі напрямки [5], як: передбачення на основі геномних даних ймовірності виникнення того чи іншого захворювання з подальшою розробкою профілактичної індивідуальної схеми; перехід від традиційної клінічної до персоналізованої діагностики захворювання з урахуванням індивідуальних показників пацієнта, з подальшим збереженням біоматеріалу протягом всього його життя; вибір тактики лікування з урахуванням індивідуальних показників пацієнтів, у т. ч. моніторинг лікування за допомогою біомаркерів, так звана тераностика; фармакологічні аспекти, що включають індивідуальний підбір лікарських засобів шляхом поєднан- 
ня геномних передбачень і терапевтичного лікарського моніторингу.

Все викладене переконує в тому, що потреба в другому етапі розвитку медицини - синтезі накопичених знань і впливі на організм як на єдине ціле - є закономірною і нагальною.

Інтегративна медицина вимагає проведення додаткових високотехнологічних тестів, що, здавалося б, зумовлює здорожчання медичних послуг. Однак в остаточному підсумку її використання веде до істотної економії витрат на медичну допомогу: при правильно поставленому діагнозі і тактиці лікування відповідні витрати різко скорочуються. Більш того, застосування персоналізованих методів істотно скоротить смертність не лише безпосередньо від захворювань, але і від невірно призначених лікарських засобів [5].

Основною перешкодою в розвитку інтегративної медицини поряд із поки ще високою вартістю необхідних досліджень вважають недостатню підготовленість фахівців, великий розрив між наданими нею новими цінними діагностичними та терапевтичними можливостями і здатністю практичних лікарів оцінити їх і застосувати на практиці [5].

Важливою перевагою інтегративного підходу до вивчення медицини є розвиток клінічного мислення у майбутніх лікарів. “Клінічне мислення” - це процес цілеспрямованого, методично правильного використання клініцистом теоретичних знань для вирішення лікарських завдань. 3 огляду на багатоетапність діагностичного процесу, слід мати на увазі не лише загальні принципи і спрямованість розумових операцій, але особливу увагу необхідно звернути на розробку методичних прийомів, що визначають характер і особливості клінічного мислення на кожному етапі роботи лікаря. Для ефективної розпізнавальної діяльності лікар повинен здійснити ряд послідовних чисто розумових і поведінкових операцій, результатом яких є прийняття деякого роду рішень, інтегрованих у кінцевий результат або заключний акт, який визначається як діагноз [8].

\section{Список літератури}

1. Сучасні технології викладання теми “Функціональні гастроінтестинальні розлади у дітей (відповідно до Римських критеріїв IV)” на VI курсі медичного факультету / О. П. Волосовець, С. П. Кривопустов, В. Є. Хоменко, О. В. Мозирська // Медична освіта. 2017. - № 3. - C. 87-90.

2. Балуєва О. В. Формування стратегічних напрямів діяльності вищих медичних навчальних закладів, спрямованих на удосконалення підготовки медичних кадрів /
Саме тому найуспішніше, 3 практичної точки зору, інтегративна медицина розвивається в області тераностики. Цей термін утворено від словосполучення “терапія” і “діагностика” і означає медичний підхід, коли перед призначенням лікарської терапії пацієнта оцінюють на предмет того, чи буде така терапія ефективною і безпечною [5]. Інтегративна діагностика визначається як комплекс методів традиційної і молекулярної або геномної медицини, спрямований на вивчення організму, діагностику захворювань і прогнозування можливої патології. Системний підхід зумовлює використання методів фізикального, генетичного, конституційного, імунологічного, антропологічного та інших видів обстеження [8].

Перевагою інтегративної діагностики на основі використання клінічних і фундаментальних наук $€$ можливість виявити і зрозуміти як анатомо-функціональні, так і психосоматичні особливості людини. Якщо до цього додати методологію аналізу кожної фази, кожного періоду: передхвороби, преморбідного періоду, розпалу захворювання, репарації та/ або реконвалесценції, реабілітації, одужання або трансформації в хронічний процес, то стає зрозумілим, що саме такий аналіз дозволяє побачити особливості індивідуального розвитку і перебігу захворювання і намітити план індивідуальної профілактики, персоніфікує терапію, реабілітацію та прогноз захворювання [8].

Висновок. Таким чином, принципи інтегративної медицини є найбільш перспективними для подальшого теоретичного розвитку і мають безумовні практичні переваги, оскільки, грунтуючись на ідеї єдиного механізму розвитку хвороб, обумовленого закономірними процесами життєдіяльності, передбачають більш раціональні шляхи пошуку ефективних засобів профілактики і лікування, ніж доктрина, заснована на припущенні, що хвороби виникають тільки під впливом випадкових причин, тобто з причинно-наслідкового хаосу.

О. В. Балуєва // Державне управління: удосконалення та розвиток. - 2013. - № 12. (Електронне наукове фахове видання.)

3. Васильев А. П. Медицина на пути к интеграции / А. П. Васильев, Н. Н. Стрельцова // Сибирский медицинский журнал. - 2014. - Т. 29, № 2. - С. 7-14.

4. Кац Я. А. Склеротическая болезнь, интегративная диагностика и пути решения проблем хронизации и лечения болезней (обзор) / Я. А. Кац, Е. В. Пархонюк, 
С. А. Скрипцова // Саратовский научно-медицинский журнал. - 2015. - № 11 (3). - С. 268-274.

5. Персонализированная медицина: современное состояние и перспективы / И. И. Дедов, А. Н. Тюльпаков, В. П. Чехонин [и др.] // Вестник РАМН. - 2012. № 12 . - C. 4-12.

6. Whitcomb D. C. Going MAD: development of a «matrix academic division» to facilitate translating research to personalized medicine / D. C. Whitcomb // Acad Med. - 2011. Vol. 86 (11). - P. 1353-1359.

\section{References}

1. Volosovets, O.P., Kryvopustov, S.P., Khomenko, V.Ye., \& Mozyrska O. V. (2017). Suchasni tekhnolohii vykladannia temy "Funktsionalni hastrointestynalni rozlady u ditei (vidpovidno do Rymskykh kryteriiv IV)” na VI kursi medychnoho fakultetu [Modern technologies of teaching topic "childhood functional gastrointestinal disorders (According to rome criteria IV)” for 6th course students of medical faculty]. Medychna osvita - Medical Education, 3, 87-90 [in Ukrainian].

2. Baluieva, O.V. (2013). Formuvannia stratehichnykh napriamiv diialnosti vyshchykh medychnykh navchalnykh zakladiv, spriamovanykh na udoskonalennia pidhotovky medychnykh kadriv [Forming strategic directions for activities of higher medical education institutions, implemented to medical personnel training improvement]. Derzhavne upravlinnia: udoskonalennia ta rozvytok - Public administration: improvement and development, 12 [in Ukrainian].

3. Vasilyev, A.P., \& Streltsova, N.N. (2014). Meditsina na puti $\mathrm{k}$ integratsii [Medicine on the way to integration]. Sibirskiy meditsinskiy zhurnal - Siberian Medical Journal, 29 (2), 7-14 [in Russian].

4. Kats, Ya.A., Parkhoniuk, Ye.V., \& Skriptsova, S.A. (2015). Skleroticheskaya bolezn, integrativnaya diagnostika i puti resheniya problem khronizatsii i lecheniya bolezney (obzor) [Sclerotic disease, integrative diagnosis and ways
7. Гоженко А. И. Современное состояние развития теории болезни (дискуссионные заметки) / А. И. Гоженко // Науковий журнал МОЗ України. - 2014. № 2 (6). - С. 5-13.

8. Индивидуальная диагностика и концепция превентивно-предиктивно-персонифицирующей медицины / Я. А. Кац, Е. В. Пархонюк, Н. С. Акимова, Е. Н. Корсунова // Фундаментальные исследования. - 2014. № 1. - С. 124-128.

to solve the problems of chronic diseases and treatment (review)]. Saratovskiy nauchno-meditsinskiy zhurnal - Saratov Journal of Medical Scientific Research, 11 (3), 268-274 [in Russian].

5. Dedov, I.I., Tyulpakov, A.N., Chekhonin, V.P., Baklaushev, V.P., Archakov, A.I., \& Moshkovskiy, S.A. (2012). Personalizirovannaya meditsina: sovremennoye sostoyaniye i perspektivy [Personalized medicine: current status and prospects]. Vestnik RAMN - Journal of RAMN, 12, 4-12 [in Russian].

6. Whitcomb, D.C. (2011). Going MAD: development of a «matrix academic division» to facilitate translating research to personalized medicine. Acad. Med., 86 (11), 1353-1359.

7. Gozhenko, A.I. (2014). Sovremennoye sostoyaniye razvitiya teorii bolezni (diskussionnyye zametki) [The current state of the development of the theory of the disease (discussion notes)]. Naukovyi zhurnal MOZ Ukrainy Scientific Journal of the Ministry of Health of Ukraine, 2 (6), 5-13.

8. Kats, Ya.A., Parkhonyuk, Ye.V., Akimova, N.S., \& Korsunova, Ye.N. (2014). Individualnaya diagnostika i kontseptsiya preventivno-prediktivno-personifitsiruyushchey meditsiny [Individual diagnosis and the concept of preventive-predictive-personalizing medicine]. Fundamentalnyye issledovaniya - Basic Research, 1, 124128 [in Russian]. 